$\mathrm{K}_{\mathrm{b}}^{\mathrm{o}}$ onserwacja-restauracja książek zabytkowych wywodzi się z rzemiosła introligatorskiego i rozwinęła się na gruncie wieloletnich doświadczeń przekazywanych z pokolenia na pokolenie. Obecnie specjalistów w tej dziedzinie kształcą w Polsce dwie szkoły wyższe: Katedra Konserwacji i Restauracji Starych Druków i Grafiki Akademii Sztuk Pięknych w Warszawie [dalej: ASP] oraz Zakład Konserwacji Papieru i Skóry na Uniwersytecie Mikołaja Kopernika w Toruniu [dalej: UMK]. Kształcenie zawodowe konserwatora-restauratora książki opiera się na interdyscyplinarnej wiedzy z zakresu nauk ścisłych i humanistycznych, a także jego talencie artystycznym. Ten obszar nauki nieustannie się rozwija, poszukuje się coraz lepszych materiałów i wprowadza się nowe technologie. Niezbędne dla pełnej wiedzy i umiejętności zawodowych jest także poznanie dawnych technik i technologii. Praktyczne umiejętności z tego zakresu zdobywane są przez studentów na zajęciach prowadzonych m.in. w ramach Pracowni Introligatorstwa Artystycznego na UMK w Toruniu oraz w Pracowni Technik i Technologii Opraw na ASP w Warszawie.

Istotą działalności obu pracowni jest wprowadzenie przyszłych konserwatorów-restauratorów w świat dawnej książki i jej oprawy poprzez praktyczne realizacje wykonane zgodnie z historycznymi technikami introli-

\section{Inspiracje. Historyzujące i artystyczne oprawy kodeksów}

DOI: http://dx.doi.org/10.12775/TSB.2015.014

gatorskimi. Ponadto zdobyta praktyka, możliwość uczenia się na własnych błędach to dla każdego studenta bezcenna nauka przygotowująca do samodzielnego rozwiązywania problemów towarzyszących konserwacji-restauracji zabytkowych kodeksów.

Prowadząc przez wiele lat Pracownię Introligatorstwa Artystycznego na UMK w Toruniu, obserwowałam, jak duży potencjał twórczy drzemie w młodzieży. Pragnąc jej umożliwić wykazanie się wiedzą i talentem artystycznym, postanowiłam, że jedną z prac zaliczeniowych będzie wykonanie artystycznej oprawy książki. Zaangażowanie studentów przy wykonywaniu opraw artystycznych jest ogromne. Na moich oczach przy powstawaniu projektów uruchamia się ich kreatywność, czego wynikiem są prawdziwie artystyczne oprawy, świadczące także o warsztatowej biegłości ich twórców. Wśród prac o zbliżonym do siebie poziomie można znaleźć prawdziwe „perełki” sztuki, a nie rzemiosła introligatorskiego. Młodzi ludzie eksponują w ten sposób potrzebę kontaktu z piękną 
książką, nie tylko ze względu na treść, lecz także artefaktem pięknym materialnie. Ta wyraźna chęć obcowania z książką w artystycznej oprawie na co dzień w czasach e-booków nie jest popularna, więc tym cenniejsza.

Uznałam, że te dzieła sztuki introligatorskiej, będące efektem indywidualnej, twórczej interpretacji każdego studenta, warte są upublicznienia. Postanowiłam w związku z tym zorganizować wystawę, na której prace te zostałyby pokazane. Stwierdziłam, że interesujące będzie także zaproszenie do projektu pracowników i studentów z Pracowni Technik i Technologii Opraw ASP w Warszawie. Wystawa okazała się niezwykle cenną inicjatywą, gdyż oba środowiska po raz pierwszy wspólnie zaprezentowały efekty swej pracy dydaktycznej w zakresie introligatorstwa.

Wystawa „Inspiracje”, prezentująca prace z zakresu introligatorstwa naszych i warszawskich studentów, została zaprezentowana po raz pierwszy w Toruniu 23-24 października 2014 r. jako impreza towarzysząca targom konserwatorskim „Konserwacje” i konferencji naukowej „Wczoraj i dziś konserwacji-restauracji zabytkowych kodeksów". Cieszyła się olbrzymim zainteresowaniem i została niemalże natychmiast wypożyczona przez Bibliotekę Uniwersytecką w Toruniu, gdzie była prezentowana $\mathrm{w}$ dniach 19 listopada - 12 grudnia 2014 r. Od 13 marca do 8 kwietnia wystawa gościła w Bibliotece Elbląskiej, a 13-17 kwietnia była prezentowana w Bibliotece Głównej Uniwersytetu Kardynała Stefana Wyszyńskiego w Warszawie w ramach III Dni Książki Dawnej. Mamy nadzieję w niedalekiej przyszłości pokazać wystawę w Bibliotece Uniwersyteckiej w Warszawie oraz Centrum Sztuki Współczesnej „Znaki Czasu” w Toruniu. Tak duże zainteresowanie jest niewątpliwym sukcesem naszych i warszawskich studentów.

Na wystawie można zobaczyć historyzujące oprawy książek wykonane przez studentów warszawskiej ASP, które w katalogu opatrzone są odrębnym słowem wstępnym, oraz oprawy tzw. książek artystycznych wykonane przez studentów uczelni toruńskiej. Uważam, że właściwe w tym miejscu będzie przedstawienie choćby pokrótce prezentowanych na wystawie obiektów i ich autorów wraz z inspiracjami, które im towarzyszyły.

Oprawy historyzujące wykonane przez studentów Katedry Konserwacji i Restauracji Starych Druków i Grafiki na Wydziale Konserwacji i Restauracji Dzieł Sztuki ASP w Warszawie obejmowały przykłady oprawy mniszej (autor Michał Kożurno), sakwowej (autor Małgorzata Grzelec), kopertowej (autor Magdalena Borkowska) oraz przykłady różnych opraw z tzw. grzbietówką (autorzy: Magdalena Borkowska, Anna Pomorska, Paula Pań- 
czyk, Maciej Wieczorek, Małgorzata Grzelec, Michał Kożurno). Wszystkie książki zostały wykonane pod kierunkiem Wojciecha Chrościckiego, Doroty Dzik-Kruszelnickiej, Zofii Koss.

Oprawa mnisza (fot. 1) jest przykładem oprawy organicznej, której charakterystyczną cechę stanowi skóra naciągnięta jedynie na grzbiet i część desek. Pozwalało to na stworzenie funkcjonalnej oprawy przy jednoczesnej oszczędności drogiego materiału, jakim była skóra. W późnym średniowieczu znalazła powszechne zastosowanie w księgach wykonywanych w warsztatach przyklasztornych.

Oprawa sakowa (fot. 2) to ciekawy przykład organicznej oprawy kodeksu w deski z wykorzystaniem dodatkowego płata skóry w dolnej części książki, umożliwiającego związanie węzła i przytroczenie do pasa. Rozwiązanie to było stosowane od XIV do końca XVI w., szczególnie na terenach Niemiec, a także we Francji, Hiszpanii, Włoszech, Anglii, Skandynawii. 0 jego popularności świadczą liczne przedstawienia tego typu opraw w sztuce. Do dziś zachowały się jedynie 23 egz.

Oprawa kopertowa (fot. 3) z klapką jest interesującym przykładem oprawy i jej dekoracji, jaki wytworzyła kultura islamu. Blok szyto na plątniki, nie stosowano wyokrąglenia grzbietu. Okładki, wykonane ze sklejonych warstw pergaminu lub papieru, docinano równo z blokiem i po zaciągnięciu skórą dołączano do bloku. Charakterystyczna, pięciokątna klapka zachodząca na przednią okładkę stanowiła przedłużenie tylnej okładziny. Misternie dziergane kapitałki wystawały ponad krawędzie okładek. Specyficzny był też sposób i motywy dekoracji ${ }^{1}$.

Niezwykle interesujące są także inspiracje, które były bezpośrednim asumptem do wyboru formy oprawy artystycznej wykonanej przez studentów UMK. Pozwolę sobie na przytoczenie kilku wybranych.

Karolina Komsta: Zaprojektowana przeze mnie książka jest dowcipem, swoistą wariacją na temat książki sensu stricto. Jej forma została zainspirowana słowami Williama Blake’a: If the doors of perception were cleansed everything would appear to man as it is: Infinite. Jeśli zdecydujemy się otworzyć te drzwi, czeka nas niespodzianka - kolejne drzwi..., a za nimi tabula rasa. Naszym zadaniem jest wypełnić ją słowami... Książkę oprawiono w białą skórę, a przednią okładzinę potraktowano jak drzwi zachęcające

${ }^{1}$ Opisy książek do katalogu towarzyszącego wystawie przygotowane przez Dorotę Dzik-Kruszelnicką, Monikę Dzik, Julię Kłosińską, Zofię Koss, Annę Nicewicz, Piotra Popławskiego. 


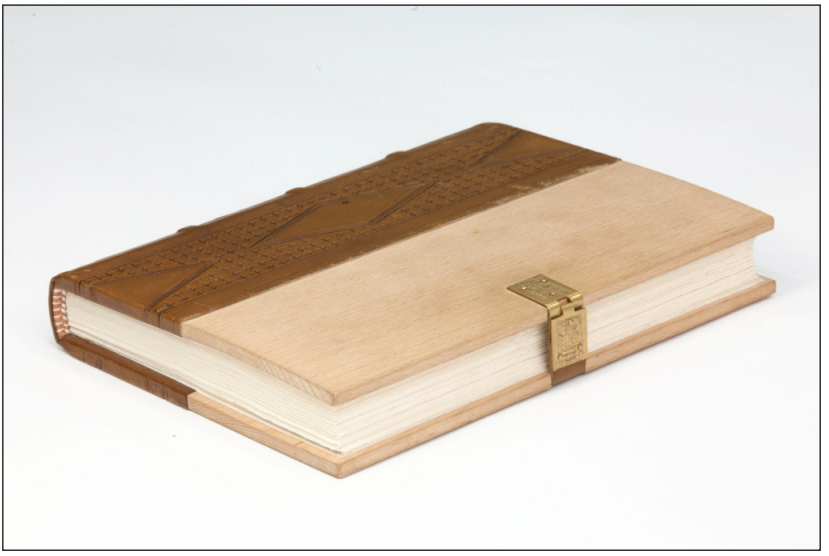

Fot. 1. Oprawa mnisza

Źródło: Wystawa

„Inspiracje” 2014.

Fot. Tomasz Kozielec

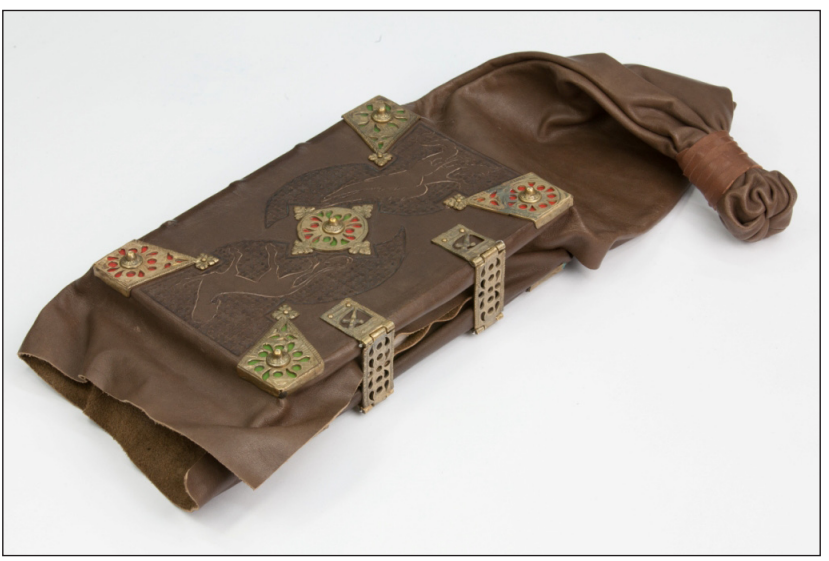

Fot. 2. Oprawa sakwowa Źródło: Wystawa „Inspiracje” 2014. Fot. T. Kozielec

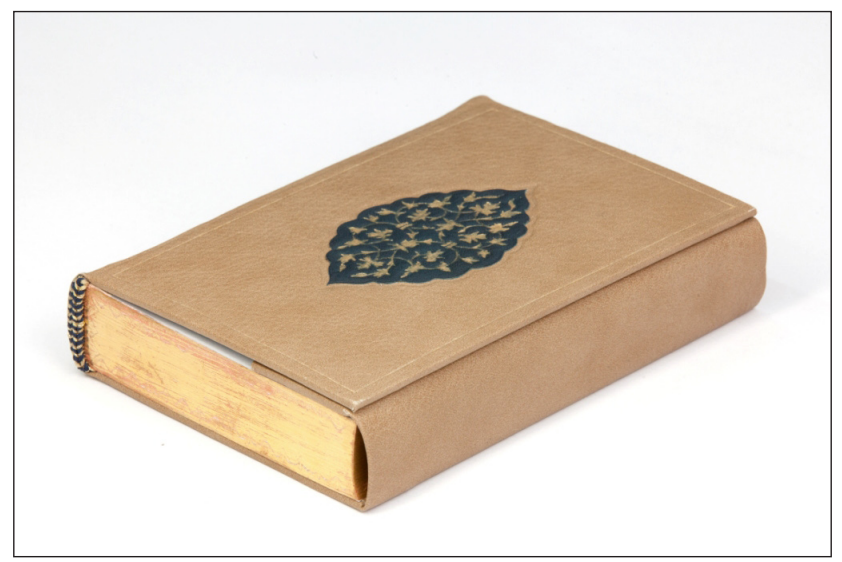

Fot. 3. Oprawa kopertowa Źródło: Wystawa „Inspiracje” 2014. Fot. T. Kozielec 
Fot. 4. Oprawa autorstwa Karoliny Komsta Źródło: Wystawa „Inspiracje” 2014. Fot. T. Kozielec

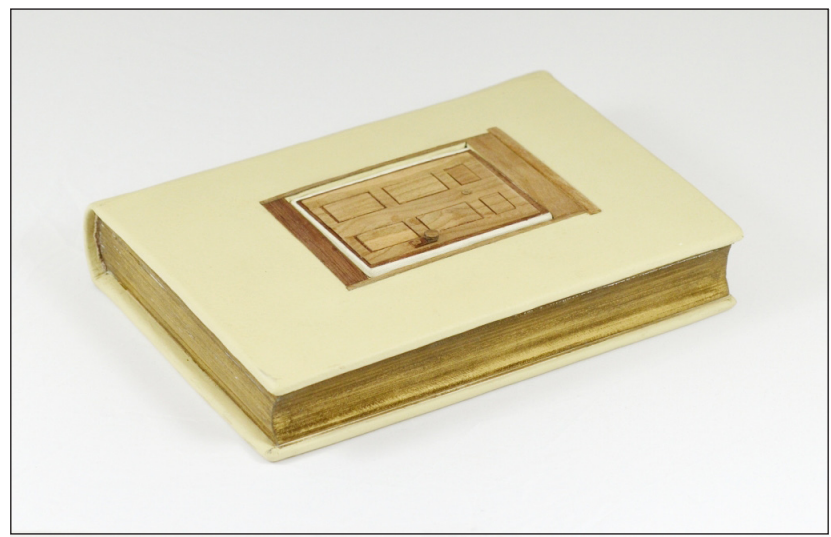

Fot. 5. Oprawa autorstwa Aleksandry Dziedzic Źródło: Wystawa „Inspiracje” 2014.

Fot. T. Kozielec

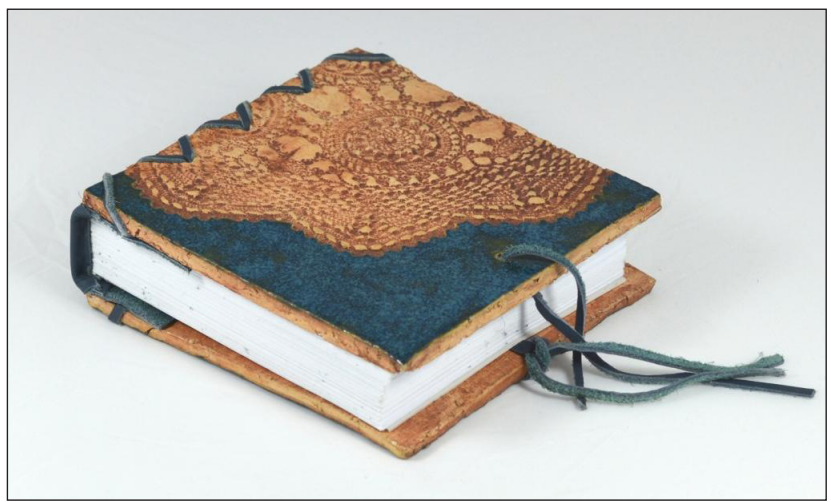

do wejścia. Za nimi znajduje się kolejna, mniejsza książka wiązana szyfonowymi wstążkami. Drzwi wykonano $\mathrm{z}$ forniru $\mathrm{w}$ technice intarsji. Wnętrze ozdobiono wzorzystą dublurą (fot. 4).

Marta Kłosiewicz: Wykonana przeze mnie oprawa inspirowana była projektem tkaniny Williama Morrisa artysty, który postulował odrodzenie rzemiosła artystycznego. Wzór przedstawiający tulipany i liście wierzby wyszyłam w technice haftu wypukłego cieniowanego na zafarbowanym wcze- śniej materiale. W wybranych miejscach przyszyłam przeźroczyste kolorowe koraliki i cekiny.

Joanna Kilian: Pieczenie jest sposobem na odstresowanie się, daje chwilę zapomnienia i wyciszenia w zabieganym świecie. W prezentowanych książkach połączyłam obie moje miłości - do książek i do ciast. Przepis na ciasto „książkę”: Wziąć kilkadziesiąt arkuszy papieru złożonych na pół, taśmy i nici, składniki odpowiednio połączyć. Uzyskaną masę od grzbietu 
usztywnić klejem skrobiowym i papierem długowłóknistym. Według uznania, by efekt był ładniejszy, można dodać warstwy malowane farbami akrylowymi. Następnie należy zająć się ciastem - z tektury wykonać grzbietówkę oraz okładziny, przełożyć kremem. Jeśli całość nie jest wystarczająco słodka - dodać skórę na obleczenie. Udekorować porzeczkami z koralików lub kleksem bitej śmietany z papier-mache. Smacznego!

Ewa Langowska: Oto historia powstania książki-torebki: najpierw znalazłam tkaninę, której wzór bardzo mi się spodobał. Zastanawiałam się nad tym, jak najlepiej wyeksponować bogato haftowane płótno. Doszłam do wniosku, że powinno to być coś kobiecego i niebanalnego zarazem. Pomyślałam o formie torebki, która jest bardzo kobiecym atrybutem. Ozdobiłam ją kokardą i paskiem ze złotego łańcuszka, który może służyć także jako zakładka. Tak oto powstała torebeczka dla kobiety intelektualistki.

Aleksandra Dziedzic: Inspiracją do stworzenia tej książki stało się zamiłowanie do ceramiki, a szczególnie zabytkowych pieców kaflowych i płytek naściennych. Ich połyskujące szkliwo i zupełnie współczesne trendy w ceramice, jak np. odciskanie dekorów w surowej glinie, stało się punktem wyjścia do samodzielnego stworzenia okładzin w pracowni ceramicznej. Kolor został wybrany pod wpływem inspiracji tureckimi płytkami z Hagia Sophia, będącymi wspaniałym przykładem subtelnego smaku w ceramice (fot. 5).

Roksana Misztal: Wykonana przeze mnie książka artystyczna łączy smukłe i subtelne proporcje formatu tzw. dutki z masywnymi i zdobionymi okładzinami. Dutka (folio fracto) to format karty używanej w staropolskich kancelariach oraz w księgach sądowych. Jej wymiary to ok. $40-50$ x 10-14 cm. Do okładzin, obleczonych wcześniej skórą, zamontowałam blachy miedziane z samodzielnie wytrawionym $w$ nich ornamentem. Inspiracją dla okładzin były oprawy klejnotowe. Motywy zdobnicze zaczerpnięto z oprawy pochodzącego z VIII w. karolińskiego Lindau Gospel. Jako zapięcie zastosowano pięć miedzianych zapinek. Krawędzie bloku pozłociłam. Format i sposób zapięcia jest inspirowany XIX-wiecznymi sztambuchami. Książka artystyczna powstała przez połączenie odmiennych cech książek z różnych epok.

Magdalena Niedźwiadek: Kość słoniowa to jeden z najcenniejszych materiałów, z którego od dawna wykonywano luksusowe przedmioty zbytku. Szczególną jego popularność można zaobserwować w dekoracyjnej sztuce secesji. Dlatego też do stworzenia projektu książki, z głównym elementem zdobniczym imitującym ten szlachetny surowiec, jako inspiracja posłużyła mi plansza autorstwa Eugène'a Gras- 
seta z wzornika ornamentów secesyjnych L'animal dans la décoration, wydanego w 1897 r. w Paryżu. Książka obleczona jest w zielony aksamit. Dekoracyjny panel imitujący kość słoniową został wykonany w technice odlewu z formy silikonowej przy wykorzystaniu kazeiny i żywicy akrylowej $\mathrm{z}$ dodatkiem odpowiednio dobranych pigmentów (fot. 6).

Aleksandra Cybul: Długo myślałam nad odpowiednim projektem, miałam wiele pomysłów, ale przede wszystkim chciałam wykorzystać jakiś nietypowy materiał. Wybrałam ptasie pióra.

Osobiście lubię minimalizm, pragnęłam również w wysublimowany, nienachalny sposób zawrzeć w książce klimat grozy. Zdecydowałam się na dominację czerni - jednego z moich ulubionych kolorów. Książkę oblekłam w czarną skórę, a „pierzasty wachlarz” umieściłam na obu okładzinach. Aby przełamać czerń, postanowiłam wprowadzić czerwone akcenty. Dodałam także szczyptę blasku w formie srebrzonych krawędzi bloku oraz koralików występujących na zakończeniu zakładki oraz ozdobnych aplikacjach na oprawie. Po odpowiednim otworzeniu książki i spojrzeniu na nią od strony oprawy ujawnia się pierzasty stwór z czerwonymi oczami i wystawionym czerwonym językiem. Oczy tworzą koralikowe aplikacje na okładzinie, a dolne zakończenie zakładki jawi się jako język (fot. 7).
Marta Świtoń: Inspiracją do stworzenia tak nietypowej oprawy była moja fascynacja Bajkami robotów Stanisława Lema, książką zawierającą przeróżne fantastyczne historie o robotach i cybernetyce, do której nadal często powracam. Tytuł książki i autor pojawiają się na wyświetlaczu LCD wykonanej przeze mnie książki. Wielki wpływ na zrealizowanie takiego właśnie projektu miał także mój entuzjazm dla walk robotów, zauroczenie samymi robotami oraz znajomość z konstruktorami i programistami maszyn automatycznych (fot. 8).

Piotr Tylicki: Inspiracją do stworzenia tej książki-albumu jest moje zainteresowanie odtwórstwem historycznym - podziwiam ludzi, którzy własnoręcznie wykonują odzież oraz przedmioty użytku codziennego wzorowane na historyczne. Album ma także wymiar praktyczny, może służyć do przechowywania pamiątkowych fotografii. Album oprawiony został w skórę cielęcą i ozdobiony historyzującym celtyckim wzorem, wypalonym w skórze przedniej okładziny.

Do uczestnictwa w wystawie zaprosiłam także Kasię Rosik, która przy mojej pomocy zrealizowała aneks do swojego dyplomu „Prêt-à-écrire”2. Jak pisze

22009 r. - dyplom na kierunku edukacja artystyczna - współpromotor prof. Jędrzej Gołaś. Praca ta została nagrodzona Medalem Boguckiego - nagrodą za najlepszy dyplom na tym kierunku. 


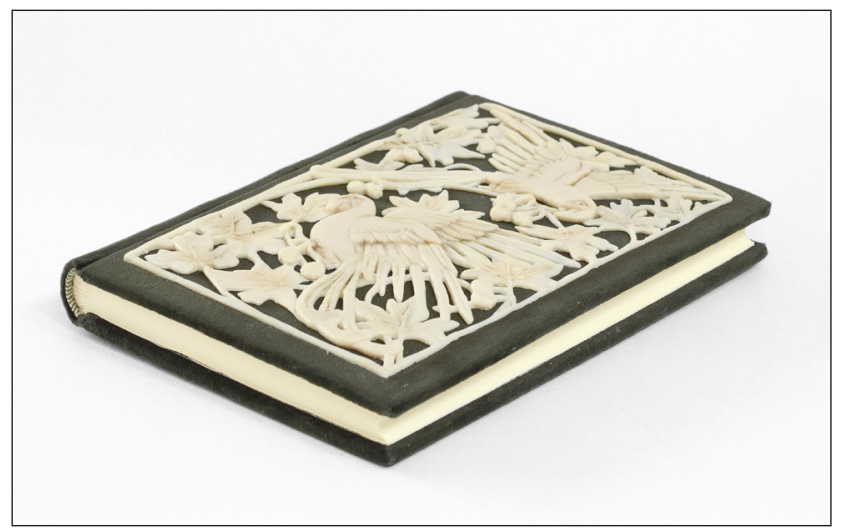

Fot. 6. Oprawa autorstwa Magdaleny Niedźwiadek Źródło: Wystawa „Inspiracje” 2014. Fot. T. Kozielec

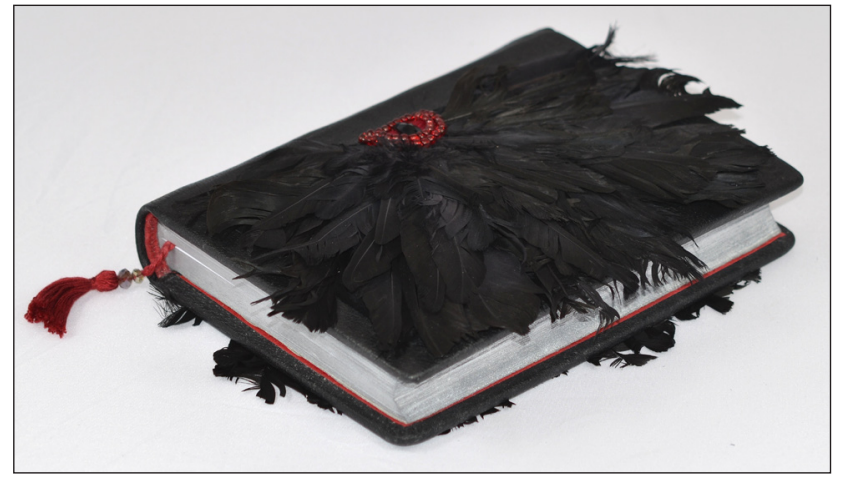

Fot. 7. Oprawa autorstwa Aleksandry Cybul Źródło: Wystawa „Inspiracje” 2014. Fot. T. Kozielec

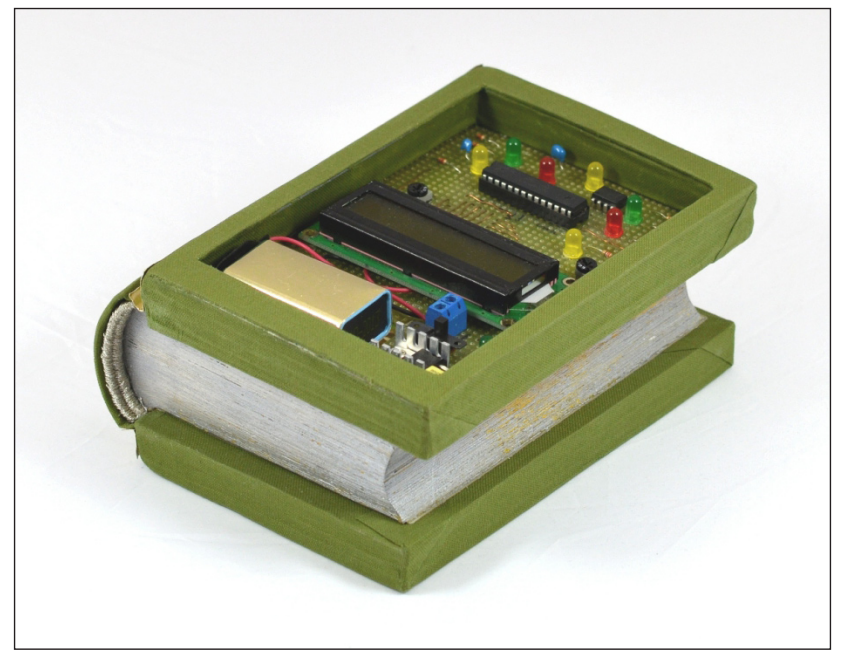

Fot. 8. Oprawa autorstwa Marty Świtoń Źródło: Wystawa „Inspiracje” 2014. Fot. T. Kozielec 
Fot. 9. Oprawa autorstwa Katarzyny Rosik Źródło: Wystawa „Inspiracje” 2014. Fot. T. Kozielec

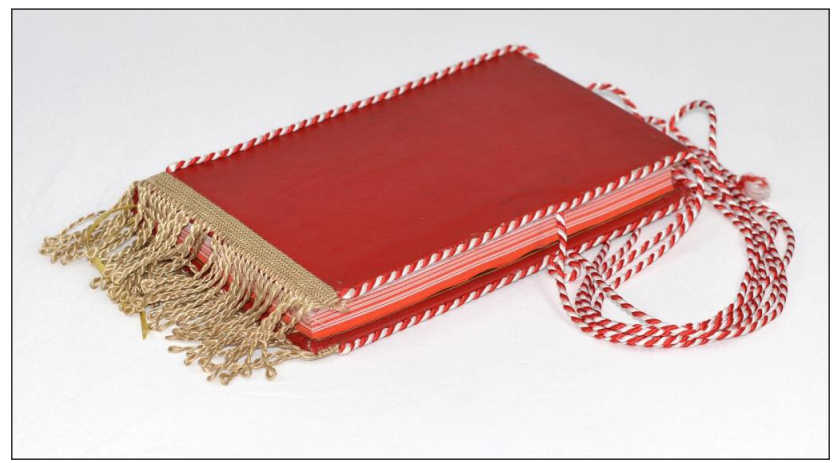

autorka, „Kolekcja Prêt-à-écrire powstała ze skrzyżowania dwóch przedmiotów codziennego użytku - zeszytu i torby, których forma w znakomitej większości przypadków podlega ściśle zasadom ergonomii człowieka i zrodziły się dlatego tylko, by być użytecznymi. Proces kształtowania się obydwu przedmiotów rozpoczął się tysiące lat temu i wydaje się, że doszliśmy do doskonałości, nie tylko poprzez znalezienie odpowiednich materiałów, formatów, praktycznych rozwiązań, ale również przez różnorodność projektową, dzięki której schlebia się gustom wielu. Wydawać by się mogło, że wszystkie możliwości zostały już wyczerpane, ale obecne czasy nie pozwalają spocząć twórcom. Współczesny użytkownik też jest spragniony nowych kombinacji, dostarczając wiele radości projektantom, którzy mogą wprowadzić swoje koncepcje do produkcji i do wykorzystania w codzienności. Seria torbo-zeszytów wykonanych tradycyjnymi technikami jako proto- typy obiektów, które mogłyby zostać wprowadzone do masowej produkcji. Łączą ze sobą funkcjonalność obu przedmiotów, czasem dodając trzeci, jak poduszka czy proporczyk (fot. 9), ale ich forma sugeruje cel i warunki wykorzystywania".

Z prawdziwą przyjemnością zaprezentowałam oprawy artystyczne moich studentów, wykonane po rocznej nauce w Pracowni Introligatorstwa Artystycznego. Pragnę im wszystkim podziękować i z całego serca pogratulować, życząc jednocześnie każdemu z nich wspaniałej drogi zawodowej, na której można się zrealizować nie tylko naukowo, ale także artystycznie. Ufam, że nigdy nie stracą artystycznego ducha i w każdym elemencie życia będą umieli znaleźć inspirację do tworzenia sztuki.

Serdecznie dziękuję Agnieszce Ziębie i Tomkowi Kozielcowi za wyjątkowe zaangażowanie $w$ organizację wystawy i przygotowanie katalogu, a także Wojtkowi Chrościckiemu, Do- 
rocie Dzik-Kruszelnickej i Zosi Koss z ASP w Warszawie za współorganizację tego przedsięwzięcia.

Mam nadzieję, że uda nam się zrealizować nasze zamierzenia i wystawę będzie można jeszcze obejrzeć w naj- bliższym czasie we wspomnianych wyżej instytucjach.

\section{Małgorzata Pronobis-Gajdzis Zakład Konserwacji Papieru i Skóry Uniwersytetu Mikołaja Kopernika w Toruniu}

$\mathrm{O}$ becnie wzrasta znaczenie popularyzacji nauki, również w zakresie wykorzystywanych w jej ramach narzędzi. Zaadaptowanie tychże na potrzeby dziedzin uważanych jeszcze do niedawna za hermetyczne i elitarne nie jest sprawą łatwą, szczególnie gdy są one jednocześnie z różnych powodów dziedzinami niedocenianymi w świadomości odbiorców i mocno zaniedbanymi na gruncie doświadczeń propagatorskich ${ }^{1}$.

Artykuł jest próbą zarysowania możliwości promocji artystycznego dorobku Zygfryda Gardzielewskiego

* Artykuł powstał na podstawie komunikatu wygłoszonego $\mathrm{w}$ charakterze użytkownika zbiorów 10 grudnia $2014 \mathrm{r}$. z okazji jubileuszu 40-lecia Sekcji Dokumentów Życia Społecznego Biblioteki Uniwersyteckiej w Toruniu [dalej: DŻS BUT].

1 Zob. A. Frontczak, Słowo wstępnewybrane aspekty reklamy z perspektywy projektowania graficznego [online]. „Zeszyty Naukowe" 2013, nr 4 (Reklama wizualna), s. 7-8 [dostęp: 30 czerwca 2015]. Dostępny w World Wide Web: http://wsp.pl/ file/1217_404616253.pdf.

\section{Zygfryd Gardzielewski - toruński twórca kultury. 0 perspektywach popularyzacii spuścizny artysty typografa*}

DOI: http://dx.doi.org/10.12775/TSB.2015.015

i jego osoby dzięki materiałom pozostawionym w jego spuściźnie. Jest także pretekstem do przyjrzenia się działaniom dokumentującym dziedzictwo toruńskiego typografa w kontekście rosnącego zainteresowania polską sztuką typograficzną i typografią w ogóle.

W zbiorach Sekcji Dokumentów Życia Społecznego Biblioteki Uniwersyteckiej w Toruniu [dalej: DŻS BUT] znajduje się przekazana w 2005 r. przez Janinę Gardzielewską spuścizna po niej i jej mężu Zygfrydzie. Ten niezwykły zbiór obejmuje oryginalne dokumenty, dyplomy, odznaki, medale, wycinki prasowe, nagrania radiowe i vi- 